\title{
Translation and adaptation of the Phlebitis Scale for the Portuguese population
}

\author{
Tradução e adaptação da Phlebitis Scale para a população portuguesa \\ Traducción y adaptación de la Phlebitis Scale para la población portuguesa \\ Luciene Muniz Braga*; Anabela de Sousa Salgueiro-Oliveira**; Maria Adriana Pereira Henriques**; \\ Manuel Alves Rodrigues****; Cláudia Jesus Vidal Rodrigues*****; Sónia Alexandra Graça Pereira*****; \\ Pedro Miguel dos Santos Dinis Parreira*******
}

\begin{abstract}
Background: The use of a scale such as the Phlebitis Scale is recommended to assess phlebitis since it allows standardizing the assessment and documenting care effectiveness.

Objectives: To translate, adapt, and assess the psychometric properties of the Phlebitis Scale for the Portuguese population. Methodology: Methodological study of translation and assessment of the psychometric properties of the Phlebitis Scale in a nonprobability sample with 110 patients using 526 peripheral venous catheters. An exploratory factor analysis was performed with Varimax rotation in principal components for analyzing the construct validity and internal consistency of the scale using Cronbach's alpha coefficient.

Results: A 35.5\% of phlebitis incidence was observed. The factor analysis revealed 2 levels of severity, with the first grade explaining $41.5 \%$ of variance. Internal consistency was .78 and .90 .

Conclusion: The Escala Portuguesa de Flebite (Portuguese Phlebitis Scale) showed linguistic equivalence to the original and adequate internal consistency for assessing phlebitis. However, a new scale structure is proposed to improve the interpretation and identification of the grades of phlebitis.
\end{abstract}

Keywords: nursing; phlebitis; peripheral catheterization; translation; factor analysis

\section{Resumo}

Enquadramento: Para avaliação da flebite é indicada a utilização de uma escala como a Pblebitis Scale, que possibilita padronizar a avaliação e documentar a efetividade dos cuidados.

Objetivos: Traduzir, adaptar e avaliar as propriedades psicométricas da Phlebitis Scale para a população portuguesa.

Metodologia: Estudo metodológico de tradução e avaliação das propriedades psicométricas da Pblebitis Scale numa amostra não probabilística com 110 doentes portadores de 526 cateteres venosos periféricos. Realizou-se análise fatorial exploratória em componentes principais com rotação Varimax para análise de validade de constructo e análise da consistência interna da escala através do Alpha de Cronbach. Resultados: Observou-se uma incidência de 35,5\% de flebite nos doentes. A análise fatorial evidenciou 2 graus de severidade da flebite, o primeiro responsável por $41,5 \%$ de variância. A consistência interna foi 0,78 e 0,90 .

Conclusão: A Escala Portuguesa de Flebite demonstrou equivalência linguística em relação à original e consistência interna adequada na avaliação da flebite. No entanto, propõe-se nova estrutura da escala para melhorar a interpretação dos graus de flebite em termos de discriminação.

Palavras-chave: enfermagem; flebite; cateterismo periférico; tradução; análise fatorial

\footnotetext{
* MSc, RN, Professor, Federal University of Viçosa, Viçosa - MG, 36570.900, Brasil lluciene.muniz@ufv.br]. Address for correspondence: Rua Rosalina Silva Santos 153/201 Bairro Fátima, 36570-000, Viçosa, Brasil. Contribution to the article research design, data collection, data analysis and interpretation, article writing and approval of the final version. * Ph.D., RN, Adjunct Professor, Nuring School of Coimbra, 3046-851, Coimbra Portugal [anabela@esenfc.pt].

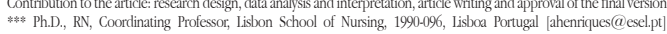
Contribution to the article: research design, data analysis and interpretation, article writing and approval of the final version. ***** Ph.D., Agregaçäo, Principal Coordinating Professor. Scientific Coordinator of the Health Sciences Research Unit Nursing, Nursing School of Coimbra, 3046-851, Coimbra, Portugal [manuel.rodrigues @esenfc.pt]. Contribution to the article: research design, data analysis and interpretation, article writing and approval of the final version. ****** RN., RN, Coimbra Hospital and University Center, 3000-075, Coimbra, Portugal [civrodrigues@ @otmail.com]. Contribution to the article: data collection, article writing and approval of the final version. Fas*a* RN., RN, Coimbra Hospital and University Center, 3000-075, Coimbra, Portugal [soniagracapereira@gmail.com. Contribution to the article: data collection, article writing and approval of the final version. Contribution to the article research design, data analysis and internereation, article writing and a approal of the final version.
}

\section{Resumen}

Marco contextual: Se indica el uso de una escala como la Phlebitis Scale para evaluar la flebitis. Así, se estandariza la evaluación y se documenta la eficacia de los cuidados.

Objetivos: Traducir, adaptar y evaluar las propiedades psicométricas de la Pblebitis Scale para la población portuguesa.

Metodología: Estudio metodológico de la traducción y evaluación de las propiedades psicométricas de la Pblebitis Scale en una muestra no probabilística de 110 pacientes con 526 catéteres venosos. Se realizó el análisis factorial exploratorio sobre los componentes principales con rotación Varimax para analizar la validez de constructo y la consistencia interna de la escala mediante el coeficiente alfa de Cronbach. Resultados: Se observó una incidencia de flebitis en los pacientes del $35,5 \%$. El análisis factorial reveló dos grados de severidad de la flebitis, el primer grado explica el $41,5 \%$ de la varianza. La consistencia interna fue 0,78 y 0,90 .

Conclusión: La Escala Portuguesa de Flebitis demostró una equivalencia lingüística en relación a la original y una consistencia interna adecuada en la evaluación de la flebitis. Sin embargo, se propuso una nueva estructura de la escala para mejorar la interpretación de los grados de flebitis en cuanto a la discriminación.

Palabras clave: enfermería; flebitis; cateterismo periférico; traducción; análisis factorial

Received for publication: 14.06 .16

Accepted for publication: 16.11 .16 


\section{Introduction}

Phlebitis is an inflammation of the inner lining of a vein as a reaction to tissue damage associated with the use of peripheral venous catheter (PVC), and it can be identified based on multiple signs and symptoms (Maki \& Ringer, 1991; Athayde \& Oliveira, 2006). It is a complication that leads to the removal of almost half of PVCs (Oliveira, 2014), and that affects patient comfort, catheter indwell time, hospital length of stay, and treatment costs (Pasalioglu \& Kaya, 2014).

The use of an echographer for assessing vein caliber, blood flow, and signs of phlebitis in patients who require intravenous treatment has been suggested (LaRue \& Peterson, 2011), as well as the use of a visual phlebitis scale to assess the signs and/or symptoms of phlebitis, helping professionals make decisions about the need for PVC replacement (Gallant \& Schultz, 2006).

Several studies have assessed the incidence and risk factors of phlebitis (Abolfotouh, Salam, Bani-Mustafa, White, \& Balkhy, 2014; Oliveira, 2014; Pasalioglu \& Kaya, 2014; Webster et al., 2015). However, there has been no consensus on the different scales used to assess phlebitis, which prevents their international comparison.

A systematic literature review identified 71 scales for phlebitis assessment. However, not all of them were analyzed in psychometric studies, which may lead to differences in the incidence of phlebitis, hampering comparison (Ray-Barruel, Polit, Murfield, \& Rickard, 2014). According to the same study, the most widely used phlebitis scales are the Phlebitis Scale, the Visual Infusion Phlebitis, the Baxter Scale, and the Maddox Scale (Ray-Barruel et al., 2014). We found no phlebitis scale validated for the Portuguese population.

The lack of a phlebitis scale validated for Portugal based on psychometric studies, and the need to assess the incidence of phlebitis encouraged the translation, cultural adaptation, and assessment of the psychometric properties of the Phlebitis Scale, which was published by the Infusion Nurses Society in 2006. So, the main purpose of this study was to translate, adapt, and assess the psychometric properties of the Phlebitis Scale for the Portuguese population.

\section{Background}

Intravenous therapy is one of the most widely used clinical interventions in hospital settings (Ho \& Cheung, 2012), being one of the steps implemented through peripheral venipuncture, which consists of several steps, from material selection and PVC placement to the assessment of the patient's clinical condition, even after catheter removal (Sena, Krempser, Silva, \& Oliveira, 2013). This process is not without risk and phlebitis stands out as the most highly incident complication (Oliveira, 2014; Pasalioglu \& Kaya, 2014; Infusion Nurses Society, 2006).

The following associated factors should be highlighted: PVC indwell time; catheter gauge; PVC insertion site, health professional's technical expertise; PVC maintenance care; insertion site care and frequency of dressing replacement; infusion characteristics; and the patients' profile (Pasalioglu \& Kaya, 2014; FerreteMorales et al., 2010; Ferreira, Pedreira, \& Diccini, 2007; Maki \& Ringer, 1991).

The Infusion Nurses Society (2006) recommends that phlebitis rates should be lower than $5 \%$. However, the studies report rates between $7 \%$ and $68.9 \%$ (Abolfotouh et al., 2014; Oliveira, 2014; Pasalioglu \& Kaya, 2014; Webster et al., 2015). The variability of results concerning phlebitis incidence may be due to the lack of consensus on the measures used for assessing phlebitis, preventing the meaningful comparison of phlebitis rates (Ray-Barruel et al., 2014). Thus, the use of quality indicators seems to be important to improve the quality of care in order to monitor, measure, and compare, both internally and externally, the obtained results. Nurses should also identify patients with risk factors associated with the development of phlebitis and implement preventive measures so as to prevent other major complications, such as thrombophlebitis and infection (Ho \& Cheung, 2012; Gabriel et al., 2011).

International organizations (Infusion Nurses Society, 2006; Royal College of Nursing, 2010) have recommended the use of a scale to assess and document the grade of phlebitis, which could inform the decision for PVC removal and prevention of symptom progression.

The Phlebitis Scale was developed by Alyce Schultz and Paulette Gallant and published by the Infusion Nurses Society (2006). It is one of the most widely accepted and used scales for phlebitis assessment 
(Gallant \& Schultz, 2006; Infusion Nurses Society, 2006). It is easy and quick to apply (average of 1.3 minutes), and it is considered a valid, clinically feasible, and reliable measure to determine when a PVC should be removed (Groll, Davies, MacDonald, Nelson, \& Virani, 2010; Gallant \& Schultz, 2006).

The Phlebitis Scale is graded from 0 to 4 , and each level includes signs and/or symptoms of phlebitis. Grade 0 indicates the absence of phlebitis and the other grades indicate the presence of phlebitis. Grades 3 and 4 are associated with clinical signs of thrombophlebitis due to thrombus formation in the vessel wall, and are characterized by pain and palpable venous cord along the vein. The presence of initial symptoms, such as the pain associated with erythema, indicate the removal of the venous catheter (Infusion Nurses Society, 2006).

\section{Research Question}

Taking into account the various phlebitis scales already published, the lack of a scale adapted to the Portuguese population, and the need to use a scale for identifying the early signs/symptoms of phlebitis, as well as assessing and documenting the grade of phlebitis in nursing practice, we developed this study to answer the following question: Is the Portuguese version of the Phlebitis Scale valid and clinically feasible for assessing the grade of phlebitis in patients with PVCs in the Portuguese population?

\section{Methodology}

This study consisted of the process of translation and cultural and linguistic adaptation of the Phlebitis Scale into European Portuguese, as well as the assessment of its psychometric properties in terms of validity and reliability in clinical practice. The translation and adaptation complied with the international guidelines recommended by Sousa \& Rojjanasrirat (2011), and consisted of five steps: translation of the scale into Portuguese; synthesis; back-translation; draft version in Portuguese; and final version, proposed by an expert panel. The study was previously approved by the Infusion Nurses Society and the Ethics Committee for Health of the Coimbra Hospital and University Center (Reference: CHUC-020-15).
Step 1 - Translation

Two independent Portuguese native bilingual translators were recruited to translate the Phlebitis Scale from English into European Portuguese (one translator was a nurse and the other had no knowledge of health terminology).

Step 2 - Synthesis

Based on the translations, we elaborated the Portuguese version of the Phlebitis Scale (Synthesis I), which was compared to the original English version. The items that lacked consensus among the translators were analyzed concerning any ambiguities and discrepancies in the words, sentences, and meanings at a consensus meeting with the research team (two Ph.D. Nursing Professors with expertise in research on phlebitis; two Ph.D. Professors with experience in the process of scale validation; a MSc. teacher attending a Nursing doctoral degree with experience in intravenous therapy). After reaching a consensus, the Synthesis II version was elaborated.

Step 3 - Back-translation

The Synthesis II version of the Phlebitis Scale was back-translated by two independent English native bilingual translators. One of the translators had academic training but no clinical experience in the health area, and the other one had no knowledge in the health area.

Step 4 - Draft version in Portuguese

To assess ambiguities and discrepancies, obtain a Portuguese version equivalent to the Phlebitis Scale, and reach consensus, the research team analyzed the English version, the Synthesis II version in Portuguese, and the back-translated version. Based on the consensus achieved, the Synthesis III version was drawn up.

Step 5 - Expert panel

The proposal of the scale in Portuguese (Synthesis III version) and the original version in English were analyzed and compared by a panel composed of seven experts with the purpose of obtaining semantic, idiomatic, experimental, and conceptual equivalence in Portuguese (three nurses from a medicine unit with 10-20-years of experience in venipuncture; two Ph.D. Nursing Professors with experience in research on phlebitis; a Portuguese Ph.D. Nursing Professor with expertise in management and research; and one of the translators who was responsible for the back-translation and had a Nursing degree). The analysis by the expert panel resulted in the final version of 
the Escala Portuguesa de Flebite, with an overall agreement of $80 \%$.

Step 6 - Clinical study of the psychometric properties After the steps of translation and back-translation, the psychometric properties of the version of the Escala Portuguesa de Flebite were assessed in clinical practice, using a sample consisting of 110 patients admitted to a medicine unit of a hospital in the central region of Portugal, with one or more PVCs, in a total of 526 PVCs. The study included patients aged 18 years or more with a medical prescription for intravenous therapy at the moment of admission, indicating the need for insertion of one or more PVCs. Patients with central venous catheters or who refused to participate in the study were excluded.

The Escala Portuguesa de Flebite was applied by the nurses working in the unit before the administration of intravenous medication, or before and during continuous infusions, or during the performance of other nursing care interventions in case of signs of phlebitis; the scale was not applied after PVC removal. Data were collected between July and October 2015, and patients were followed up from hospital admission to discharge.

Data were organized and analyzed in the Statistical Package for the Social Sciences (SPSS), version 21. Descriptive analysis (measures of central tendency and variability), percentage and exploratory factor analysis on principal components were performed to analyze construct validity. The Kaiser-Meyer Olkin (KMO) index was used to measure if the data were adequate for factor analysis, the Bartlett's test was used to verify if the data met the sphericity prerequisite, and then a Varimax rotation was performed to assess construct validity. The internal consistency of the scale was analyzed using the Cronbach's alpha coefficient. The level of significance was set at $5 \%(\alpha=.05)$.

\section{Results}

The process of translation of the Phlebitis Scale into European Portuguese associated with the bilingual method showed satisfactory results. Both translations were close to the literal meaning of the Phlebitis Scale. The items in which there was no consensus in the translation were discussed and reviewed by the research team, and the following decisions were made:

With regard to the clinical criterion No symptoms, we opted for the translation Sem sintomas because it facilitates the understanding of the lack of clinical signs and/or symptoms of phlebitis. With regard to Streak formation, translated as Filão ruborizado ao longo do percurso da veia, we opted for the adaptation Rubor ao longo do percurso da veia because, besides being the most adequate expression for the inflammatory process that may occur in the vein due to the increased blood flow to the dilated superficial capillaries, rubor (redness) is a term used in nursing clinical practice in Portugal.

With regard to the clinical criterion Purulent drainage, we opted for Drenagem purulenta, because the term refers to the occurrence of yellowish exudate on the PVC insertion site, which, in association with the other clinical criteria, may characterize the phlebitis grade 4 . After consensus on the translation, the Synthesis II version of the Escala Portuguesa de Flebite was elaborated and back-translated. Only one of the 10 clinical criteria was different between the backtranslation and the original version: Streak formation, which was translated into Portuguese as Rubor ao longo do percurso da veia and back-translated as Redness along the vein path by both translators involved in the back-translation. The research team kept the translation in the Portuguese version, as they believed that it did not change its meaning.

Then, the research team and one of the translators performed a qualitative analysis on the linguistic adequacy of the original version of the Phlebitis Scale, the Synthesis II (Portuguese) version, and the back-translation. The Synthesis II version of the scale in Portuguese was approved. Afterwards, the scale was examined by an expert panel regarding its cultural adequacy, level of understanding, and interpretation. The professionals in this panel made no new suggestions and concluded that the version proposed for the Escala Portuguesa de Flebite was a proper representation of the English original version and that it was adequate in shape and vocabulary to the proposed objective (Table 1). 
Table 1

Proposed version of the Escala Portuguesa de Flebite

\begin{tabular}{ll}
\hline Grau & Critérios Clínicos \\
\hline 0 & Sem sintomas \\
1 & Eritema no local do acesso com ou sem dor \\
2 & Dor no local do acesso com eritema ou edema \\
3 & Dor no local do acesso com eritema ou edema \\
& Rubor ao longo do percurso da veia \\
& Cordão venoso palpável \\
4 & Dor no local do acesso com eritema e/ou edema \\
& Rubor ao longo do percurso da veia \\
& Cordão venoso palpável $>2,5$ cm de comprimento \\
& Drenagem purulenta \\
\hline
\end{tabular}

The application of this scale was analyzed in a sample of 110 patients, with a mean age of 79 years $(18-96 ; S D \pm 13.0)$ and a median of 82 years (Q1 = $77.0 ; \mathrm{Q3}=86.0$; Table 2). The mean age of patients

Table 2

Sample distribution by gender and age $(N=110)$ who developed phlebitis was 82 years (59 - 94; SD \pm $8.2)$ and the median age was 83 years $(Q 1=78.0$; $\mathrm{Q} 3=89.0)$.

\begin{tabular}{lccccc}
\hline Age & $18-39$ & $40-59$ & $60-79$ & Over 80 & Total \\
\cline { 2 - 6 } & $n(\%)$ & $n(\%)$ & $n(\%)$ & $n(\%)$ & $n(\%)$ \\
\hline Male & - & $3(2.5)$ & $21(19.0)$ & $28(25.5)$ & $52(47.0)$ \\
Female & $2(2.0)$ & $3(2.5)$ & $13(12.0)$ & $40(36.5)$ & $58(53.0)$ \\
\hline
\end{tabular}

Based on the observation of the PVC insertion site and adjacent areas using the proposed version of the Escala Portuguesa de Flebite, it was possible to identify 60 PVCs with clinical signs of phlebitis in 39 patients (incidence of phlebitis per patient of $35.5 \%$ ), i.e. one to seven phlebitides were identified in patients throughout intravenous therapy (26 patients had one phlebitis, nine patients had two phlebitides, three patients had three phlebitides, and one patient had seven phlebitides). Of the 60 PVCs with clinical signs of phlebitis, 38 phlebitides were documented as being Grade 1 (7\%), 15 as Grade 2 (3\%), and 7 as Grade 3 (1.5\%). No Grade 4 phlebitides were observed.

The indwell time of these 60 PVCs between PVC insertion and identification of phlebitis was on average 3.5 days (1-22 days; $S D \pm 4$ ). A percentage of $30 \%$ of phlebitis was identified in the first 24 hours of catheter insertion.

Erythema at access site was the most common clinical sign of phlebitis (91.5\%), followed by pain (63.5\%), edema (35\%), streak formation (15\%), and palpable venous cord (13.5\%).

In the assessment of the psychometric properties of the proposed version of the Escala Portuguesa de Flebite, the adequacy of the sample was analyzed using the KMO Measure of Sampling Adequacy, having obtained the value of .64, and a Bartlett's test of sphericity $\left(\chi^{2}(10)=1215.50 ; p<.001\right)$, which showed statistical significance. These indicators showed that the data were appropriate to proceed with a factor analysis. Then, a Varimax rotation solution was performed. We accepted items with commonalities $>.61$ and loadings $\geq .78$. The solution revealed two dimensions, which showed two levels of severity: the first explained $41.5 \%$ of variance and the second $37.7 \%$, in a total of $79.2 \%$ of the total variance. Cronbach's alpha coefficient was .78 and .90 for the first and second dimensions, respectively, showing values of internal consistency, as can be seen in Table 3 . 
Table 3

Loadings, percentage of explained variance, communalities $\left(b^{2}\right)$, and internal consistency of the proposed version of the Escala Portuguesa de Flebite

\begin{tabular}{lccc}
\hline \multirow{2}{*}{ Clinical criteria of the Escala Portuguesa de Flebite } & \multicolumn{3}{c}{ Factors, \% of explained variance and communalities } \\
\cline { 2 - 4 } & F1 & F2 & b \\
\hline Eritema no local do acesso & .854 & $37.7 \%$ & .734 \\
Dor no local do acesso & .837 & & .803 \\
Edema & .776 & .320 & .608 \\
Cordão venoso palpável & & .946 & .911 \\
Rubor ao longo do percurso da veia & & .936 & .906 \\
Cronbach's alpha & .78 & .90 & \\
\hline
\end{tabular}

Note. F1 - Severity level $1 ; \mathrm{F} 2$ - Severity level $2 ; h^{2}$ - Communalities.

\section{Discussion}

In terms of lexicon, the Phlebitis Scale is a simple scale, a fact that was confirmed in its translation and adaptation into Portuguese, having obtained a $70 \%$ of agreement in the translated items, despite minor differences in the translation which had no major influence in terms of meaning. The participation of a translator with knowledge of the technical terms in the health area and the researchers' experience were extremely important in the process of adaptation of the Phlebitis Scale for the Portuguese population. The translation and adaptation of the Phlebitis Scale for European Portuguese is an important contribution to nursing research and clinical practice to the extent that now there is a scale adapted to the Portuguese context. The assessment of the psychometric properties of the scale based on the analysis of its construct validity showed that its clinical criteria expressed the indicators to be measured. The Cronbach's alpha of .78 and .90 for internal consistency shows that the scale is valid and reliable to assess the grade of phlebitis, although, since this is the first study in the Portuguese population, further studies should be conducted in other contexts.

The solution found showed two levels of severity, with high loadings, particularly on the items eritema no local do acesso and dor no local do acesso for the first level, and on the items cordão venoso palpável and rubor ao longo do percurso da veia for the second level of severity, indicating discriminatory ability. The item edema had a low loading, probably because it is a less common sign of phlebitis, with higher incidence in infiltration.
When analyzing the incidence of phlebitis, taking into account all the catheters inserted in patients during their hospitalization, we found a phlebitis incidence of $35.5 \%$, which is lower than that found in another study conducted in a population of Portuguese patients with very similar characteristics (42.4\%; Oliveira, 2014) and also lower (11.5\%) when the unit of analysis was the number of catheters removed due to phlebitis, with an incidence of $43 \%$ and $23.2 \%$ in other studies (Furtado, 2011; Oliveira, 2014). We believe that these results should be carefully analyzed since different phlebitis assessment tools were used. The higher incidence of phlebitis was found in grade $1(7 \%)$ and grade $2(3 \%)$, which is a lower percentage in grade 2 than that found by Oliveira (2014), and Furtado (2011; 35.1\% and 38.8\%), respectively. Although these studies have used different scales, the clinical criterion in grade 2 includes the same signs and/or symptoms. The vast majority of PVCs with signs/symptoms of phlebitis in this study was removed within 24-48 hours (58.5\%), with nurses showing good assessment and surveillance skills for the early identification of signs of phlebitis. In view of the early identification of phlebitis, with consequent PVC removal, and taking into account that the erythema is the most evident clinical sign (91.5\%), the short PVC indwell time (3.5 days) is justified, a result that is similar to other studies (Furtado, 2011; Oliveira, 2014).

The use of the Escala Portuguesa de Flebite in clinical practice standardizes the assessment of the PVC insertion site and adjacent areas that are at risk of developing phlebitis. The results of this scale indicate an adequacy to clinical practice for the assessment 
and documentation of care effectiveness, thus being considered as a valid and reliable instrument (Ho \& Cheung, 2012). Taking into account that the identification of phlebitis begins with the analysis of the signs and symptoms resulting from an inflammatory reaction and that these signs/symptoms are evident even after PVC removal (post-infusion phlebitis), we recommend the assessment of the PVC insertion site and adjacent areas not only during catheter placement but also for at least 48 hours after PVC removal (Infusion Nurses Society, 2006; Webster et al., 2015).

One aspect that motivated our proposal for changing the scale's structure was the fact that pain is a sign of real or potential tissue damage (White \& Stein, 2010) and the main reason for the removal of $3 \%$ of the catheters in the studied sample. However, the Phlebitis Scale does not consider pain as a sign of phlebitis if it is not associated with another sign/ symptom (Infusion Nurses Society, 2006). Therefore, we recommend that more attention should be given to pain, followed by PVC removal and replacement in a distant site whenever this sign/symptom is present. We suggest that the PVC should be preferably placed in the opposite limb, in a site without clinical signs of vascular trauma, in order to prevent the unintended administration of irritant and/or vesicant medication, which may result in further tissue damage.

The use of the proposed version of the Escala Portuguesa de Flebite in a clinical setting revealed some inconsistency in the analysis and interpretation of grades 1 and 2 of phlebitis: the erythema associated with pain can be characterized as grade 1 or grade 2 , because both grades have the same criteria, with a slight difference concerning the presence of edema in grade 2. Taking into account that this aspect does not allow distinguishing grade 1 from grade 2 and the importance of paying attention to pain as one of the possible early signs of phlebitis, we propose a new version of the Escala Portuguesa de Flebite which includes pain during the PVC administration of fluids as the first sign of grade 1 phlebitis, since we believe that the scale should be self-explanatory, instead of creating misunderstandings concerning its grading and interpretation. We also suggest the inclusion of the connector $\mathrm{OU}(\mathrm{OR})$ in the clinical criteria in grade 1 and the connector $\mathrm{E}$ (AND) in the clinical criteria in grades 2 to 4 to characterize these phlebitis grades, in which all signs should be highlighted, as shown in Table 4.

Table 4

Grades and clinical criteria of the new version of the Escala Portuguesa de Flebite

\begin{tabular}{ll}
\hline Grau & Critérios Clínicos \\
\hline 0 & Sem sintomas \\
1 & Dor no local ou áreas adjacentes ao cateter durante a administração de solução ou medicamento, OU \\
& Eritema no local do acesso com ou sem dor \\
2 & Dor no local do acesso E edema E eritema \\
3 & Dor no local do acesso E eritema OU edema, E \\
& Rubor ao longo do percurso da veia, E \\
& Cordão venoso palpável \\
& Dor no local do acesso E eritema E/OU edema, E \\
& Rubor ao longo do percurso da veia, E \\
& Cordão venoso palpável $>2,5$ cm de comprimento, E \\
& Drenagem purulenta \\
\hline
\end{tabular}

We believe that the new version of the Escala Portuguesa de Flebite (Table 4) addresses a limitation of the original scale, since it raised some interpretation issues concerning the presence of pain associated with erythema, without edema, in grades 1 and 2. Thus, this research constitutes an advance in clinical research, particularly to the extent that it clarifies the procedure for phlebitis assessment in Portugal. The evidence from clinical practice and the factor analysis results add new knowledge to the extent that they clarify and positively identify signs and/or symptoms of phlebitis.

It should be noted that this study had some limitations, such as the nonprobability sampling technique, which did not allow us to extrapolate the results to the population. Furthermore, the study was carried out in a hospital of the central region of Portugal, where phlebitis was documented by the nurses working in 
the unit. This may have biased the results, although we took some precautionary measures, such as having a single researcher explaining nurses how to use the scale and how to monitor and assess the catheter insertion site on a daily basis. The lack of assessment of the catheter insertion site for a period longer than 48 hours for the identification of postinfusion phlebitis was also a limitation.

\section{Conclusion}

This study resulted in the first version of the Escala Portuguesa de Flebite, which proved to be valid and reliable, with a high internal consistency for phlebitis assessment. The use of this scale in clinical practice allowed documenting a 35.5\% incidence of phlebitis among patients. However, it was only after using this scale in clinical practice that we were able to conclude that both the original scale in English and its Portuguese version had some inconsistencies in the interpretation of grades 1 and 2 of phlebitis. With the purpose of avoiding inconsistencies, facilitating the interpretation of the phlebitis grades, and distinguishing between grade 1 and 2 (since both grades had the same clinical criteria - pain and associated erythema), we suggest the inclusion of the Boolean descriptor $\mathrm{E}$ (and) between the clinical criteria dor no local do acesso E edema E eritema in grade 2 , since the presence of pain and associated edema do not characterize phlebitis but infiltration. We also suggest the inclusion of the Boolean connector E (AND) between the clinical criteria of grades 3 and 4 . In grade 1 , we suggest the inclusion of a new clinical criterion Dor no local do acesso ou áreas adjacentes ao cateter durante a administração de solução ou medicamento, given the importance of pain in the inflammatory process, which is one of the first symptoms of phlebitis, being responsible for the removal of $3 \%$ of the catheters.

The factor analysis allowed us to identify two levels of severity in the scale. However, in clinical practice, upon the identification of any grade of phlebitis, nursing interventions lead to the immediate removal of the catheter, followed by a differentiated therapeutic clinical intervention according to the severity of the symptoms within each grade of phlebitis.

The systematic assessment of phlebitis using this scale could contribute to the nurses' decision-making process concerning the implementation of therapeutic interventions and the analysis of the effectiveness of the implemented preventive measures. We suggest that further studies should be conducted in other clinical settings using the new version of the Escala Portuguesa de Flebite (Table 4) in a larger sample and with monitoring after PVC removal for 48 to 72 hours.

\section{Acknowledgments}

This study is part of the Nursing doctoral program entitled Práticas de enfermagem e a segurança do doente no processo de punção de vasos e na administração da terapêutica endovenosa. The doctoral student Luciene Muniz Braga obtained a scholarship funded by the Coordenação de Aperfeiçoamento de Pessoal de Nivel Superior (CAPES) (Coordination for the Improvement of Higher Education Personnel), Brazil (Process no. 0867/14-4).

We would like to thank the translators who participated in the translation and back-translation steps, the nurses of the Medicine Unit of the Coimbra Hospital and University Center (CHUC), the teachers of the Nursing School of Coimbra who participated in the expert panel, and the nurses who participated in data collection.

\section{References}

Abolfotouh, M. A, Salam, M., Bani-Mustafa, A., White, D., \& Balkhy, H. H. (2014). Prospective study of incidence and predictors of peripheral intravenous catheter-induced complications. Therapeutics and Clinical Risk Management, 10, 993-1001. doi: 10.2147/TCRM.S74685

Athayde, A. G., \& Oliveira, A. D. (2006). Estudo da integração de sinais na avaliação da severidade de flebite associada à cateterização venosa periférica. Revista Referência, 2(3), 7-19. Retrieved from http://web.esenfc.pt/pa3/public/ index.php? module $=$ rr\&target $=$ publicationDetails\&\& id_artigo $=28 \&$ pesquisa $=$

Ferreira, L. R., Pedreira, M. L., \& Diccini, S. (2007). Flebite no pré e pós-operatório de pacientes neurocirúrgicos. Acta Paulista de Enfermagem, 20(1), 30-36. doi: 10.1590/\$010321002007000100006

Ferrete-Morales, C., Vázquez-Pérez, M. Á., Sánchez-Berna, M., Gilabert-Cerro, I., Corzo-Delgado, J. E., Pineda-Vergara, J. A., ... Gómez-Mateos, J. (2010). Incidence of phlebitis due to peripherally inserted venous catheters: Impact of a catheter management protocol. Enfermería Clínica, 20(1), 3-9. doi: 10.1016/j.enfcli.2009.10.001 
Furtado, L. C. (2011). Incidence and predisposing factors of phlebitis in a surgery department. British Journal of Nursing, 20(Suppl. 7), S16-S25. doi: 10.12968/bjon.2011.20.Sup7.S16

Gabriel, C. S., Melo, M. R., Rocha, F. L., Bernardes, A., Miguelaci, T., \& Silva, M. L. (2011). Utilização de indicadores de desempenho em serviço de enfermagem de hospital público. Revista Latino-Americana de Enfermagem, 19(5), 9 telas. doi: 10.1590/\$0104-11692011000500024

Gallant, P., \& Schultz, A. A. (2006). Evaluation of a visual infusion phlebitis scale for determining appropriate discontinuation of peripheral intravenous catheters. Journal of Infusion Nursing, 29(6), 338-345. doi: 10.1097/00129804-20061100000004

Groll, D. L., Davies, B., MacDonald, J., Nelson, S., \& Virani, T. (2010). Evaluation of the psychometric properties of the phlebitis and infiltration scales for the assessment of complications of peripheral vascular access devices. Journal of Infusion Nursing, 33(6), 385-390. doi: 10.1097/ NAN.0b013e3181f85a73

Ho, K. H., \& Cheung, D. S. (2012). Guidelines on timing in replacing peripheral intravenous catheters. Journal of Clinical Nursing, 21(11-12), 1499-1506. doi: 10.1111/j.13652702.2011.03974.x

Infusion Nurses Society. (2006). Phlebitis. Journal of Infusion Nursing, 29(1 Suppl.), S58-S59.

LaRue, G. D., \& Peterson, M. (2011). The impact of dilution on intravenous therapy. Journal of Infusion Nursing, 34(2),117123. doi: 10.1097/NAN.0b013e31820b7899

Maki, D. G., \& Ringer, M. (1991). Risk factors for infusionrelated phlebitis with small peripheral venous catheters: A randomized controlled trial. Annals of Internal Medicine, 114(10), 845-854. doi: 10.7326/0003-4819-114-10-845

Oliveira, A. S. (2014). Intervenção nas práticas dos enfermeiros na prevenção de flebites em pessoas portadoras de cateteres venosos periféricos: Um estudo de investigação-ação (Tese de doutoramento). Retrieved from http:/hdl.handle. net/10451/12149

Pasalioglu, K. B., \& Kaya, H. (2014). Catheter indwell time and phlebitis development during peripheral intravenous catheter administration. Pakistan Journal of Medical Sciences, 30(4), 725-730. doi: 10.12669/pjms.304.5067

Ray-Barruel, G., Polit, D. F., Murfield, J. E., \& Rickard, C. M. (2014). Infusion phlebitis assessment measures: A systematic review. Journal of Evaluation in Clinical Practice, 20(2),191-202. doi: 10.1111/jep.12107

Royal College of Nursing. (2010). Standards for infusion therapy: The RCN IV Therapy Forum (3 ${ }^{\text {rd }}$ ed.). Retrieved from http:// www.bbraun.it/documents/RCN-Guidlines-for-IV-therapy.pdf

Sena, C. A., Krempser, P., Silva, R. N., \& Oliveira, D. V. (2013). Punção de vasos e paleta cromática: Subsídio para pesquisa e prática clínica de enfermeiros. Revista de Enfermagem do Centro Oeste Mineiro, 3(1), 488-497. doi: 10.19175/recom. v0i0.309

Sousa, V. D., \& Rojjanasrirat, W. (2011). Translation, adaptation and validation of instruments or scales for use in crosscultural health care research: A clear and user-friendly guideline. Journal of Evaluation in Clinical Practice, 17(2), 268-274. doi: 10.1111/j.1365-2753.2010.01434.x

Webster, J., McGrail, M., Marsh, N., Wallis, M. C., Gillian RayBarruel, G., \& Rickard, C. M. (2015). Postinfusion phlebitis: Incidence and risk factors. Nursing Research and Practice, 2015, 1-3. doi: 10.1155/2015/691934

White, W., \& Stein C. (2010). Histórico, definições e opiniões atuais. In A. Kopf \& N. B. Patel (Eds.), Guia para o tratamento da dor em contextos de poucos recursos (pp. 1-5). Retrieved from http://www.iasp-pain.org/ files/Content/ContentFolders/Publications2/FreeBooks/ GuidetoPainManagement_Portuguese.pdf 
